\title{
PENYULUHAN PERSPEKTIF HUKUM PENYALAHGUNAAN MEDIA ONLINE UNTUK KONTEN PORNOGRAFI DI SMK AL-AZHAR BATAM
}

\author{
Mesri Silalahi $^{1}$, Irene Svinarky ${ }^{2}$, Nico Bangun Rezkyanto Sianturi ${ }^{3}$ \\ 1,3Program Studi Sistem Informasi, Fakultas Teknik dan Komputer \\ ${ }^{2}$ Program Studi Ilmu Hukum, Fakultas Ilmu Sosial dan Humaniora \\ Universitas Putera Batam \\ Email:mesri@ puterabatam.ac.id
}

\begin{abstract}
SMK Al-Azhar Batam is a Vocational School enriched with Islamic knowledge and practice. Many students have a smartphone, at school they use it during recess while the study hours are turned off and stored by the teacher. Its use is to access various online media to create communities, continue learning discussions, find leaming resources, add insight, seekentertainment and others. Online media that is frequently accessed: Youtube, google, Whatsapp, Instagram, Facebook, Line and others. Based on the information obtained, SMK Al-Azhar Batam does not have special learning about the ITE Law so they do not understand the ethics of using intemet and online media. Theyalso lack understanding about pornographyand related laws. The stages of its activities are the prepa ration, implementation and evaluation stages. The result is: students of SMK AL-Azhar Batam are veryenthusiastic in participating in activities, very interested in the material presented, increasingly understanding ethics in using online media, knowing ITE laws and understanding the legal status of online media abuse and the impact of pornography.
\end{abstract}

Keywords: Online media, Pornography, Legal perspective, Abuse

Abstrak. SMK Al-Azhar Ba tam a dalah SMK kejuruan yang diperkaya pengetahuan dan praktek a ga ma Isla m. Banyak siswa-siswinya mempunyai Ga dget, di sekolah dipakai padajam istirahat sedangkan jam belajar dimatikan dan disimpan guru. Kenggunaannya adalah mengakses berbagaime dia on line untuk menciptakan komunitas, melanjutkan pembahas an pembelajaran, m encari sum ber pembelajaran, menambah wa wasan, mencari hiburan dan la in sebagainya. Media online y ang sering diakses: You tu be, google, Whatsapp, Instagram, Facebook, Line dan la inlain. Berdasarkan informasi y ang diperoleh, SMK Al-Azhar Batam tidak mempunyai pembelajaran khusus mengenai Undang-Undang ITE sehingga mereka kurang memahami etika penggunaan internet dan media online. Mereka juga kurang m emahami berbagai hal terkait pornografi dan hukum yang terkait. Tahapan kegiatannya yaitu tahap persiapan, pelaks anaan, dan tahap evaluasi. Hasil pengabdian yaitu, siswa-siswiSMK ALAzhar Batam sangata ntusias mengikut i kegia tan, sangat tertarik dengan materi yang disampaikan, semakin memahami etika

dala m menggunakan media online, mengetahuiundang-undang ITE serta me maha mi status huk um penyalahgunaan media online dan dampak pornografi.

Kata kunci : Media online, Pornografi, Perspektif hukum, Penyalahgunaan

\section{PENDAHULUAN}

SMK Al-Azhar merupakan salah satu SMK di Batam yang menawarkan pendidikan umum kejuruan yang diperkaya oleh pengetahuan agama Islam dan juga pemberian praktek agama Islam. Pemberian pengetahuan tentang agama Islam ini bertujuan agar memperkuat keimanan dan juga mengembangkan potensi diri dengan akhlakul karimah. SMK ini berdiri tahun 2002 dan merupakan SMK swasta yang berdiri sendiri dan bukan cabang dari Al-Azhar yang ada di luar Kota Batam ataupun sekolah yang ada di Kairo.
SMK Al-Azhar awalnya berdiri dengan kondisi sangat sederhana dengan bangunan yang semi permanen berdinding kayu namun karena semangat juang dari seluruh Tim guru dan juga kepala sekolah serta siswanya maka di tahun 2015 SMK Al-Azhar Batam mendapatkan penghargaan ujian nasional dengan nilai IIUN: 86,91, berupa penghargaan Sebagai Sekolah yang memiliki Indeks Integritas Penyelenggaraan Ujian Nasional Yang Tinggi diberikan oleh Menteri Pendidikan Dan Kebudayaan RI Anies Baswedan (Smk-Alazhar-Batam, 2018), selain itu juga SMK Al- Azhar kini sudah memiliki gedung 
yang bagus dan luas sehingga tidak kalah bersaing dengan sekolah lainnya di Batam baik dari segi kualitas maupun kuantitas siwasiswinya.

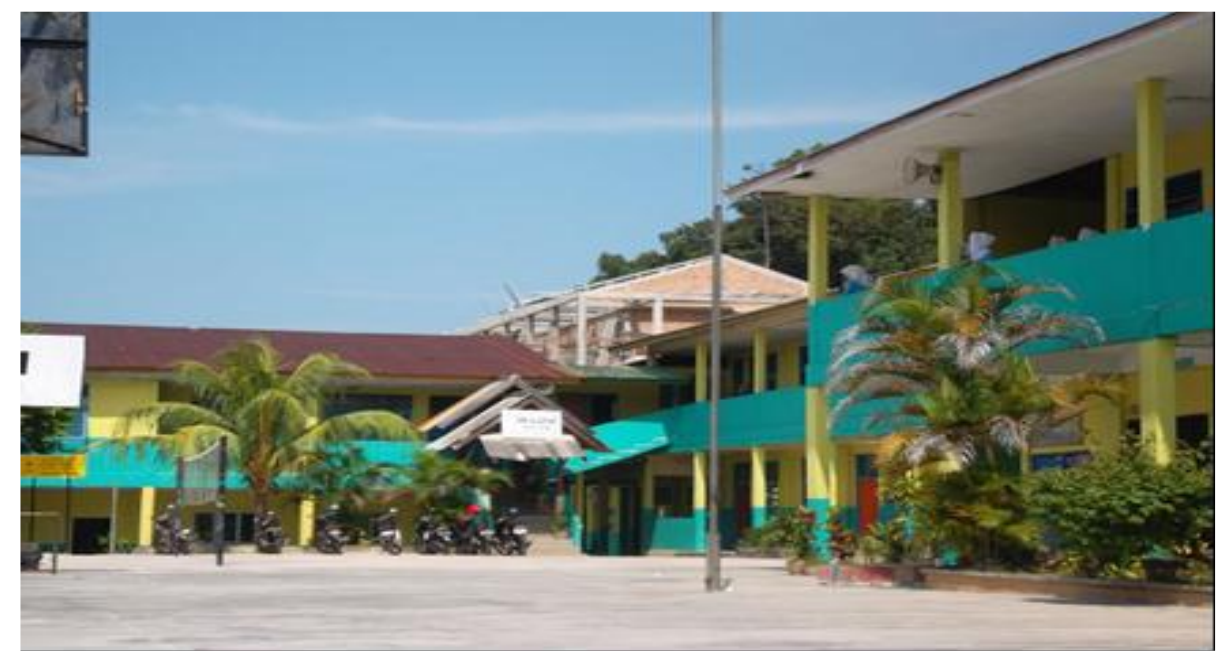

Gambar 1.SMK AL-Azhar Batam

Beberapa rincian permasalahan yang diperoleh setelah melakukan survei dan observasi ke lapangan ternyata siswa-siswi pada SMK AlAzhar banyak yang menggunakan gadget dimana gadget merupakan istilah bahasa Inggris yang memiliki arti sebuah alat elektronik kecil yang memiliki berbagai macam fungsi khusus seperti fungsi komunikasi, sosial serta pendidikan (Chusna, 2017). Berdasarkan hasil wawancara yang dilakukan, siswa-siswi SMK Al-Azhar menggunakan gadget mereka ketika jam istirahat sedangkan pada jam belajar dimatikan dan simpan oleh guru. Pembatasan penggunaan gadget ini sesuai dengan peraturan dari Kementerian Pemberdayaan Perempuan dan Perlindungan Anak dimana penggunaan gadget selama belajar, baik di sekolah dasar, sekolah menengah pertama, dan sekolah menengah atas atau sederajat disusun dengan pertimbangan bahwa penggunaan gadget selama proses pembelajaran sangat mengganggu proses belajar dan mengajar, serta berdampak negatif bagi anak bila menggunakan gadget secara berlebihan (Syifa et al., 2019). Siswa-siswi pada SMK AlAzhar biasanya menggunakan gadget mereka untuk mengakses berbagai media online dengan tujuan untuk mencari referensi belajar dan bersosial media serta hiburan, hal ini sejalan dengan (Ariston \& Frahasini, 2018) yang mengungkapkan bahwa penggunaan gadget sewajarnya telah membantu anak-anak dalam kesehariannya terutama dalam mencari data maupun informasi untuk mengerjakan tugas sekolah maupun sebagai sarana hiburan dari fitur-fitur yang disediakan dalam gadget.

Beberapa media online yang sering diakses khususnya di kalangan anak-anak sekolah diantaranya Youtube, google, Whatsapp, Instagram, Facebook, Line dan lain-lain. Dalam situs Business Dictionary, media online diartikan sebagai media digital mencakup teks, video, dan musik, yang didistribusikan melalui jaringan internet, yang termasuk media online meliputi semua jenis website dan aplikasi diantaranya: Situs berita online, Situs perusahaan, Situs ecommerce, Situs media sosial, Situs blog, Situs forum komunitas, aplikasi chatting dan lain sebagainya. Mustika (2017) juga menyebutkan bahwa, media online adalah media massa yang tersaji secara online di situs web internet. Dengan munculnya media online ini informasi dari sebuah peristiwa akan sangat cepat disampaikan. Tingginya minat masyarakat terhadap penggunaan media online saat ini mengakibatkan penggunaan internet di Indonesia semakin besar dan terus meningkat setiap harinya. Jumlah pengguna internet di Indonesia saat ini telah menguasai Asia sebesar 22,4\% (Ulinnuha, 2013).

Kehadiran media online ini sangat dirasakan manfaatnya oleh siswa-siswi SMK AlAzhar seperti menciptakan komunitas, melanjutkan pembahasan pembelajaran, 
mengatur sumber pembelajaran, mendukung materi pembelajaran, menambah wawasan, mencari hiburan dan lain sebagainya. Siswa-siswi biasanya mengakses berbagai konten sesuai dengan yang mereka inginkan tanpa adanya aturan tertentu yang harus diikuti. Siswa-siswi SMK Al-Azhar juga sering mengunggah berbagai konten ke media online dengan sesuka hati. Kemudahan untuk mengakses informasi dan berbagai aplikasi secara online membuat anakanak cenderung kesulitan memilih hal yang memang disajikan untuk anak-anak atau orang dewasa sehingga menimbulkan rasa ingin tahu anak mengenai konten-konten dewasa yang mengarah pada tindakan kriminal atau asusila, sehingga membuat mereka ingin melakukannya (Ariston \& Frahasini, 2018).

Maraknya penggunaan media online khususnya untuk jenis sosial media di kalangan para remaja khususnya anak-anak sekolah sangat berdampak pada banyak hal baik dampak positif maupun dampak negatif. Dampak positif yang dirasakan sangat banyak dan beragam. Namun selain dampak positif yang dirasakan, terdapat banyak dampak negatif yang nantinya akan berakibat buruk kepada mereka. Salah satu dampak negatif dari pemanfaatan media online yaitu terkait produksi, distribusi dan konsumsi konten pornografi. Pornografi dapat diartikan sebagai penggambaran tubuh atau aktivitas perilaku seksual manusia secara terbuka dan ditujukan untuk memicu gairah seksual pada individu yang mengonsumsinya Undang-Undang RI Nomor 44 Tahun 2008 (Kementerian Hukum dan Hak Azasi Manusia, 2008) tentang Pornografi menjabarkan pengertian pornografi sebagai gambar, sketsa, ilustrasi, foto, tulisan, suara, bunyi, gambar bergerak, animasi, kartun, percakapan, gerak tubuh, atau bentuk pesan lainnya melalui berbagai bentuk media komunikasi dan/atau pertunjukan di muka umum, yang memuat kecabulan atau eksploitasi seksual yang melanggar norma kesusilaan dalam masyarakat (Rachmaniar, Prihandini, \& Janitra, 2018). Dalam kegiatan pengabdian masyarakat ini belum ditemukan adanya tindakan pornografi yang dilakukan oleh siswa-siswi SMK ALAzhar.
Berdasarkan studi yang telah dilakukan oleh ahli psikologi perkembangan, usia remaja merupakan usia dimana seseorang sedang mencari dan membentuk identitas dirinya (Gunarsah, 2004). Karena itu, jika terpapar oleh konten pornografi tanpa dibekali oleh literasi atau pendidikan seksual yang memadai, konten tersebut akan berefek negatif terhadap perkembangan diri remaja Efek pornografi terhadap remaja terdiri dari empat tahapan yang meliputi adiksi, eskalasi, desensitisasi dan act out (Supriati \& Fikawati, 2009). Adiksi adalah tahap kecanduan, yaitu keinginan untuk mengkonsumsi pornografi kembali timbul setelah terpapar oleh konten tersebut sebelumnya. Berikutnya adalah eskalasi yaitu munculnya kebutuhan untuk mengonsumsi konten pornografi dengan muatan materi seks yang lebih berat daripada sebelumnya. Tahap yang ketiga, desensitisasi, merupakan tahap ketika materi seks yang awalnya tabu, tidak bermoral dan merendahkan martabat manusia secara perlahan dianggap sebagai sesuatu yang biasa, bahkan pada tahap ini, seseorang dapat menjadi tidak sensitif terhadap korban kekerasan seksual. Hal ini juga senada dengan pandangan ahli yang melihat pornografi sebagai bentuk subordinasi terhadap perempuan. Tahap terakhir, act out, adalah tahapan yang dapat dikategorikan sebagai tahapan yang paling nyata karena pada tahap ini, seseorang dapat mengaplikasikan perilaku seksual pornografi yang selama ini hanya dikonsumsinya. Hasil studi lainnya (McKibbin, Hamilton, \& Humphreys, 2016)yang dimuat di situs The Conversation menunjukkan bahwa anak muda yang mengonsumsi pornografi cenderung akan mengembangkan perilaku seksual abusif. Mereka yang pernah menyiksa orang lain secara seksual mengatakan bahwa jika saja mereka menerima bantuan terkait permasalahan mereka dengan pornografi, maka kecenderungan mereka untuk berlaku abusif akan berkurang (Rachmaniar et al., 2018).

Berdasarkan informasi yang diperoleh, di SMK Al-Azhar Batam tidak ada pembelajaran khusus mengenai Undang-Undang ITE sehingga mereka kurang memahami etika penggunaan internet dan media online. Untuk konten pornografi, siswa-siswi SMK Al-Azhar tidak 
memahami secara spesifik berbagai hal terkait pornografi mulai dari hal-hal yang termasuk pornografi sampai ke hukum terkait pornografi. Sebagaimana diketahui bahwa anak-anak sekolah SMA sederajat merupakan anak dengan usia pubertas maka hal-hal yang berbau pornografi sangat rentan pada usia mereka sehingga siswasiswi di SMK Al-Azhar ini sangat perlu diberikan pemahaman terkait konten pornografi pada media online sehingga mereka dapat membentengi diri mereka dan tidak tersangkut dengan kasus pornografi. Oleh karena itu kegiatan pengabdian ini bertujuan memberikan penyuluhan kepada siswa-siswi pada SMK Al-Azhar tentang etika dalam penggunaan internet dan media online, memberikan penyuluhan kepada siswa-siswi SMK Al-Azhar tentang persepsi hukum terkait dengan tindakan yang berbau pornografi melalui media online. Adapun manfaat yang diperoleh dengan diadakannya kegiatan pengabdian ini yaitu siswa-siswi pada SMK Al-Azhar Batam semakin memahami etika dalam serta dampak menggunakan internet dan media online selain itu juga mereka dapat mengetahui hal-hal yang berkaitan dengan pornografi serta sanksi hukum yang berkaitan dengan pornografi.

\section{METODE PELAKSANAAN}

Pengabdian kepada masyarakat ini dilaksanakan dengan 3 (tiga) tahapan, sebagai berikut:

\section{Tahap Persiapan}

Pada tahap persiapan, pertama tim pengabdi melakukan survey lokasi pengabdian yang beralamat di Baloi Indah, Jl. Gn Bromo, Kp. Pelita Lubuk Baja, Kota Batam, kedua mengurus perizinan pelaksanaan kegiatan pengabdian, ketiga melakukan analisis kebutuhan kegiatan, dan terakhir penyusunan materi kegiatan. Untuk menunjang kelancaran kegiatan pengabdian ini, tim pengabdi mempersiapkan beberapa peralatan dan perlengkapan sebagai berikut: 1 unit Laptop, Buku Undang-Undang, Mendownload file pdf UUITE, peralatan tulis berupa pena dan buku tulis, spanduk pelaksanaan kegiatan serta konsumsi selama kegiatan.

2. Tahap Pelaksanaan
Pengabdian ini dilaksanakan selama 2 (dua) hari berturut-turut dimana setiap pengabdi memiliki waktu selama 2 jam/sekali pertemuan untuk memberikan penyuluhan. Penyampaian materi pengabdian dilakukan dengan metode ceramah dan praktek langsung. Pertama pengabdi 1 ceramah materi tentang media online dan dilanjutkan dengan praktek langsung penggunaan media online yang memberikan manfaat positif dan berguna. Pengabdi 2 selanjutnya ceramah materi pornografi dan Undang-undang terkait pornografi selanjutnya Praktek langsung memberikan pelayanan konsultasi di bidang hukum terkait pornografi melalui media online kepada guru agar nantinya guru dapat mengatasi permasalahan jika ada siswa-siswi yang mempunyai masalah terkait pornografi. Pengabdi ketiga membantu dalam hal dokumentasi dan hal lain yang berkaitan dengan pelaksanaan kegiatan.

3. Tahap Evaluasi

Tahap akhir dari pelaksanaan kegiatan pengabdian ini dilakukan evaluasi untuk melihat hasil dari pelaksanaan kegiatan pengabdian.

Dalam melakukan evaluasi secara umum, kegiatan yang dilakukan yaitu dimana pada pertemuan akhir kegiatan tim pengabdi memberikan bebebapa pertanyaan secara tertulis berupa objektif tentang media online, pornografi serta aspek-aspek hukum terkait pornografi selanjutnya pengabdi memberikan penilaian terhadap hasil yang dikerjakan siswa-siswi pada SMK Al-Azhar, hasil ini selanjutnya diberikan kepada siswa-siswi. Kegiatan terakhir pada tahapan ini yaitu pengabdi memberikan kesimpulan terhadap hasil pengerjaan mereka.

\section{HASIL DAN PEMBAHASAN}

Sesuai dengan tahapan kegiatan yang telah ditetapkan sebelumnya yaitu tahap persiapan, pada tahap ini tim pengabdi melakukan survei lokasi pengabdian yang beralamat di Baloi Indah, J1. Gn Bromo, Kp. Pelita Lubuk Baja, Kota Batam. Pengabdi melakukan silaturahmi dengan kepala sekolah beserta beberapa guru SMK Al-Azhar, 
selanjutnya tim pengabdi melakukan sosialisasi

kelas 10 yang berjumlah lebih dari 40 orang. terkait kegiatan pengabdian kepada siswa-siswi

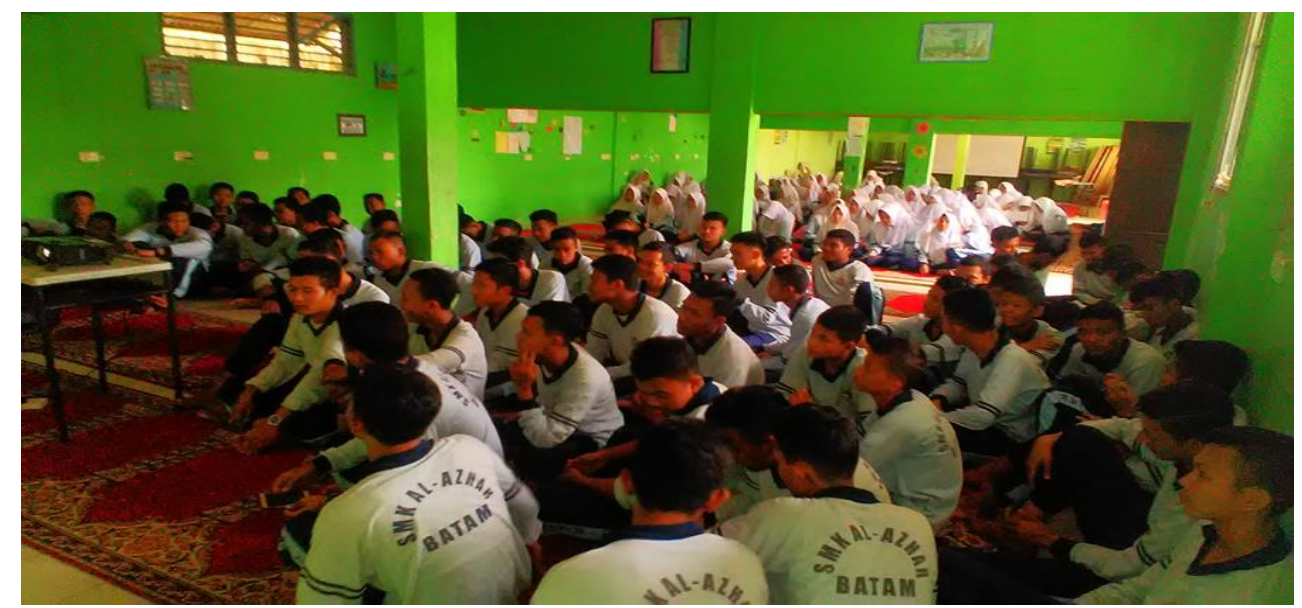

Gambar 2. Sosialiasi kegiatan pengabdian pada Siswa-siswi SMK Al-Azhar

Setelah pelaksanaan sosialisasi, tahap sosialisasi, rincian kegiatan yang dilakukan selanjutnya dilaksanakan kegiatan pengabdian pada tahap pelaksanaan sebagai berikut: sesuai dengan tema yang telah dijelaskan pada

Tabel 1.Pelaksanaan Kegiatan

\begin{tabular}{|c|c|c|c|c|}
\hline No & $\begin{array}{l}\text { Hari, } \\
\text { Tanggal }\end{array}$ & Waktu & Kegiatan & Pelaksana \\
\hline \multirow[t]{7}{*}{1} & $\begin{array}{l}\text { Sela sa, } \\
05-11-2019\end{array}$ & $13.30-13.40$ & Pembukaan (MC) & Mahasiswa \\
\hline & & $13.40-13.50$ & Sambutan (pembukaan) dariketua pengabdi & $\begin{array}{l}\text { Anggota } \\
\text { pengabdi }\end{array}$ \\
\hline & & $13.50-14.00$ & Penjelasan pornografi & $\begin{array}{l}\text { Anggota } \\
\text { pengabdi }\end{array}$ \\
\hline & & $14.00-14.10$ & $\begin{array}{l}\text { Penjela san tentang hal-hal y ang merupakan tindakan } \\
\text { pornografi }\end{array}$ & $\begin{array}{l}\text { Anggota } \\
\text { pengabdi }\end{array}$ \\
\hline & & $14.10-14.30$ & Penjela san tentang dampak pornografi & $\begin{array}{l}\text { Anggota } \\
\text { pengabdi }\end{array}$ \\
\hline & & $14.30-14.45$ & Penjela san tentang a spek hukum terkait pornografi & $\begin{array}{l}\text { Anggota } \\
\text { pengabdi }\end{array}$ \\
\hline & & $14.45-15.00$ & Penutupan(MC) & Mahasiswa \\
\hline \multirow[t]{6}{*}{2} & $\begin{array}{l}\text { Rabu, } \\
06-11-2019\end{array}$ & $10.00-10.15$ & Pembukaan (MC) & Mahasiswa \\
\hline & & $10.15-10.45$ & Penjelasan tentang media online & $\begin{array}{l}\text { Ketua } \\
\text { pengabdi }\end{array}$ \\
\hline & & $10.45-11.00$ & $\begin{array}{l}\text { Penjelasan tentang penyalahgunaan media online untuk } \\
\text { kegia tan pornografi }\end{array}$ & $\begin{array}{l}\text { Ketua } \\
\text { pengabdi }\end{array}$ \\
\hline & & $11.00-11.30$ & $\begin{array}{l}\text { Pemaparan tentang tindakan hukum sesuaidengan } \\
\text { Undang-undang ITE terkait a ksi pornografi }\end{array}$ & $\begin{array}{l}\text { Anggota } \\
\text { pengabdi }\end{array}$ \\
\hline & & $11.30-11.45$ & $\begin{array}{l}\text { Sharing peserta mengenai pengalaman mereka dalam } \\
\text { menggunakan media online dan hal-hal berkaitan } \\
\text { dengan pornografi }\end{array}$ & $\begin{array}{l}\text { Tim } \\
\text { pengabdi }\end{array}$ \\
\hline & & $11.45-12.00$ & Penutupan(MC) & Mahasiswa \\
\hline
\end{tabular}

Siswa-siswi kelas 10 SMK Al-Azhar Batam yang telah mengikuti kegiatan pengabdian diberikan pemaparan materi pornografi dimana pornografi bukanlah hal yang baru di Indonesia, banyak kasus pornografi yang menimpa khususnya anak- anak. Hal ini merupakan salah satu dampak dari perkembangan teknologi dan munculnya internet serta maraknya penggunaan media online di semua kalangan. Maraknya penggunaan media online telah membuka kemungkinan distribusi 
konten yang mudah dan cepat termasuk konten pornografi. Berdasarkan situs similarweb.com, Twitter menempati peringkat 10 situs teratas yang diakses oleh netizen Indonesia, sementara situs porno populer muncul pada peringkat 21 , 26, dan 37 yang menunjukkan tingginya akses materi pornografi oleh pengguna internet di Indonesia (Anwar, Iriani, Herman, \& Manongga, 2018). Berdasarkan hasil pengabdian yang telah dilakukan dimana media online yang paling sering mereka gunakan yaitu youtube, instagram, whatssapp, twitter, facebook.

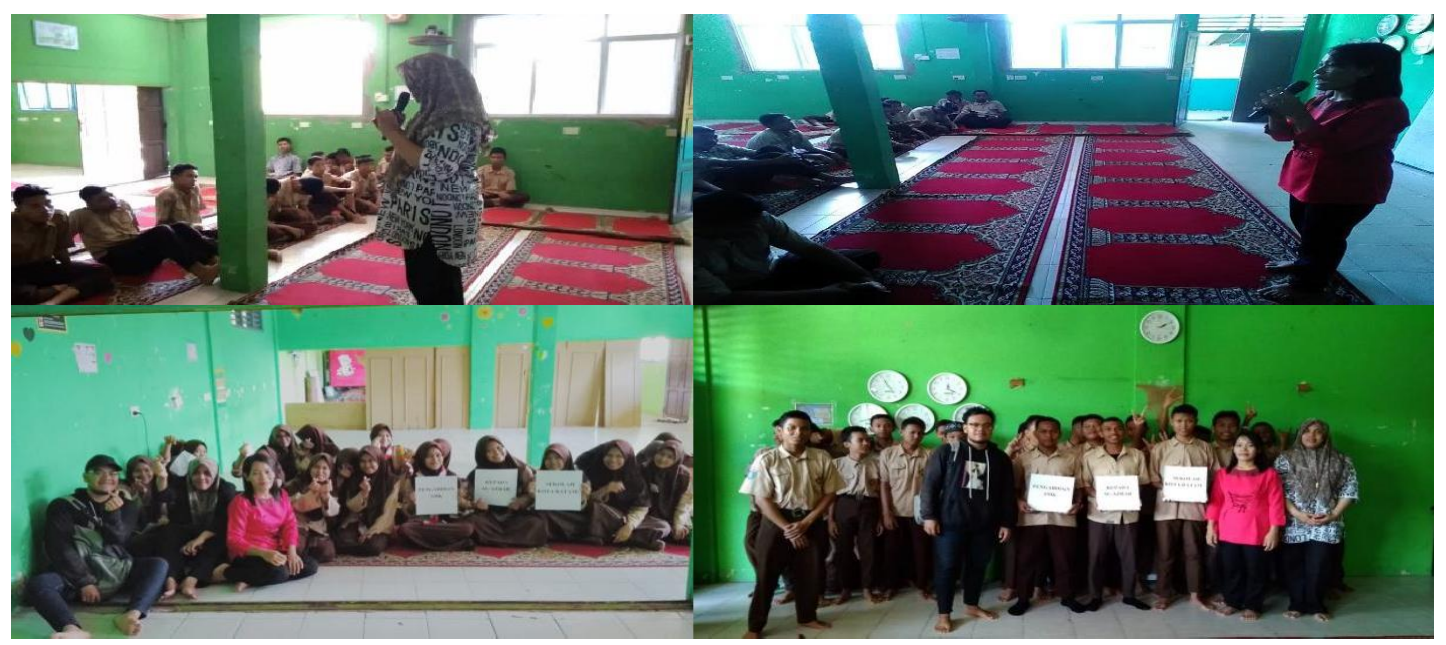

Gambar 3. Pelaksanaan Kegiatan pengabdian

Siswa-siswi SMK AL-Azhar Batam sudah tidak asing lagi dengan media online, mereka bahkan memberikan pengakuan bahwa media online sudah menjadi seperti sebuah kebutuhan. Dengan adanya media online, anakanak sekolah SMK AL-Azhar Batam semakin dipermudah dalam pencarian bahan-bahan belajar. Jika ada tugas-tugas dan mereka tidak punya buku maka mereka dapat melakukan pencarian materinya dengan memanfaatkan media online. Dengan kehadiran media online dan perkembangan teknologi maka siswa-siswi SMK AL-Azhar semakin dipermudah dalam proses belajar khususnya dimasa pandemi covid19 yang sedang melanda saat ini. Dari antara mereka juga menyebutkan bahwa anak-anak sekolah jika tidak mempunyai akun sosial media maka anak tersebut bisa dianggap gaktek. Hal ini mengakibatkan seringkali anak-anak sekolah yang akhirnya melakukan berbagai cara supaya memiliki smartphone sehingga mereka dapat ber internetan dan mengakses berbagai media online dengan mudah. Selain itu Berbagai media online yang sering diakses oleh anak-anak sekolah SMK AL-Azhar Batam sesuai informasi yang mereka sampaikan diantaranya aplikasi chatting WhatsApp, sosial media Instagram, facebook,
Line, aplikasi e-commerce gojek dan grab, situssitus blog dan lain sebagainya. Namun dari banyak aplikasi yang dipakai oleh masyarakat umum, anak-anak SMK AL-Azhar Batam mengakui bahwa media online yang sangat sering mereka pakai yaitu sosial media diantaranya WhatsApp, Instagram, facebook, aplikasi $e$ commerce gojek dan grab. Berdasarkan hasil evaluasi yang dilakukan di akhir pertemuan, pengabdi melihat bahwa peserta pengabdian yaitu siswa-siswi SMK AL-Azhar Batam telah memahami materi yang disampaikan, hal ini diukur dari skor perolehan dari soal-soal objektif yang diberikan. Pengabdi melihat bahwa siswasiswi sangat antusian dalam mengikuti semua rangkaian kegiatan pengabdian yang dilakukan sehingga diakhir kegiatan mereka mengharapkan supaya kegiatan yang sama dapat dilakukan kembali.

\section{SIMPULAN DAN SARAN}

Dari pelaksanaan kegiatan pengabdian masyarakat di sekolah SMK AL-Azhar Batam ini, maka dapat diberikan beberapa kesimpulan dan saran sebagai berikut (1 )Siswa-siswi SMK AL-Azhar Batam sangat antusias dalam mengikuti kegiatan pengabdian, peserta sangat 
tertarik dengan materi yang disampaikan, (2) Peserta yaitu Siswa-siswi SMK AL-Azhar Batam semakin memahami bagaimana etika dalam menggunakan media online, (3) Peserta juga mengetahui Undang-undang ITE,Siswa-siswi SMK AL-Azhar Batam memahami status hukum penyalahgunaan media online dan dampak pornografi.

Disarankan supaya kegiatan yang sama dapat dilakukan kembali di SMK AL-Azhar Batam maupun sekolah-sekolah lainnya mengingat bahwa penggunaan internet dan media online saat ini sudah menjadi kebutuhan apalagi dengan kondisi global yang terjadi saat ini sehingga perlu diberikan pemahaman terhadap para siswa-siswi sehingga mereka memperoleh dampak positif dari penggunaan media online dan internet.

\section{UCAPAN TERIMAKASIH}

Ucapan terima kasih disampaikan kepada Universitas Putera Batam yang telah memberikan dukungan sehingga terlaksananya kegiatan pengabdian ini. Ucapan terimakasih kasih juga disampaikan kepada pimpinan SMK Al-Azhar Batam yang telah memberikan izin dilaksanakannya kegiatan pengabdian ini. Ucapan terimakasih juga tidak lupa disampaikan kega guru-guru SMK Al-Azhar Batam serta siswa-siswa yang telah antusias dalam mengikuti setiap rangkaian kegiatan pengabdian. Selanjutnya disampaikan juga ucapan terimakasih kepada seluruh mahasiswa yang turut serta berperan sehingga kegiatan pengabdian ini dapat terlaksana dengan baik.

\section{DAFTAR PUSTAKA}

Anwar, M. T., Iriani, A., Herman, D., \& Manongga, F. (2018). Analisis Pola Persebaran Pornografi pada Media Sosial dengan Social Network Analysis. Buana Informatika, 9(1), 43-52.

Mustika, R. (2017). ANALISIS FRAMING PEMBERITAAN MEDIA ONLINE MENGENAI FRAMING ANALYSIS OF ONLINE MEDIA IN DISCLOSURE OF.
Jurnal Penelitian Komunikasi, 20(2), 135148. https://doi.org/10.20422/jpk.v20i2.159

Rachmaniar, Prihandini, P., \& Janitra, P. A. (2018). Perilaku penggunaan smartphone dan akses pornografi di kalangan remaja perempuan. Jurnal Komunikasi Global, 7(1), $1-11$.

Ulinnuha, M. (2013). MELINDUNGI ANAK DARI KONTEN NEGATIF INTERNET : Studi terhadap Peramban Web Khusus Anak. SAWWA, 8(2), 341-360.

Ariston, Y., \& Frahasini. (2018). Dampak penggunaan gadget bagi perkembangan sosial anak sekolah dasar. JOURNAL OF EDUCATIONAL REVIEW AND RESEARch, 1(2), 86-91.

Chusna, P. A. (2017). Pengaruh Media Gadget Pada Perkembangan Karakter Anak. Dinamika Penelitian: Media Komunikasi Sosial Keagamaan, 17(2), 315-330. https://eresources.perpusnas.go.id:2093/doi/abs/10.1 142/S0192415X20500500

Syifa, L., Setianingsih, E. S., \& Sulianto, J. (2019). Dampak Penggunaan Gadget terhadap Perkembangan Psikologi pada Anak Sekolah Dasar. Jurnal Ilmiah Sekolah Dasar, 3(4), 538. https://doi.org/10.23887/jisd.v3i4.22310

Ariston, Y., \& Frahasini. (2018). Dampak penggunaan gadget bagi perkembangan sosial anak sekolah dasar. JOURNAL OF EDUCATIONAL REVIEW AND RESEARch, 1(2), 86-91.

Chusna, P. A. (2017). Pengaruh Media Gadget Pada Perkembangan Karakter Anak. Dinamika Penelitian: Media Komunikasi Sosial Keagamaan, 17(2), 315-330. https://e-

resources.perpusnas.go.id:2093/doi/abs/10.1 142/S0192415X20500500

Syifa, L., Setianingsih, E. S., \& Sulianto, J. (2019). Dampak Penggunaan Gadget terhadap Perkembangan Psikologi pada Anak Sekolah Dasar. Jurnal Ilmiah Sekolah Dasar, 3(4), 538. https://doi.org/10.23887/jisd.v3i4.22310 